\title{
An Empirical Study of the Relationship between Global Competitiveness and "The South China Sea Issue" Stakeholders' Service Trade Network
}

\author{
Chang-Ping ZHAO ${ }^{\mathrm{a},{ }^{*}}$, Jian-Hua $\mathrm{QI}^{\mathrm{b}}$, Min QU ${ }^{\mathrm{c}}$ \\ Institute of Strategic Management and System Planning, DMU, Dalian 116026, China.

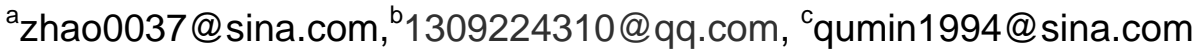

Keywords: South China sea issue, Stakeholders, Service trade network, Influence factors, ERGM.

\begin{abstract}
This paper creatively introduces the diversion thinking into the study of the South China Sea problem, and selects the global competitiveness index (2013-2014) as the measurement of the actors' characteristics of the South China Sea stakeholders. Selecting the bilateral services trade data(2013)of South China Sea issue stakeholders to build the network, using ERGM model to test the conditional probability of the relationship between Global Competitiveness Index of the indicators and the South China Sea stakeholders services trade network , and then identifies the key factorswitch have impact on the development of South China Sea stakeholders' Service Trade, on this basis to discuss the measures to promote the sustainable development of trade in services.
\end{abstract}

\section{Introduction}

The relationship between China and the Philippines has been reversed, the topic of South China situation drops. The "South China Sea Code of Conduct" that rules the South China Sea nations has a breakthrough in the negotiations. But the sovereignty dispute over the South China Sea issue will continue for a long period of time, the stability of the situation in the South China Sea and the prosperity of the Asia-Pacific region are affected by the South China Sea stakeholders' evolution of political and economic network, therefore the study on influencing factors that "South China Sea" stakeholders' service trade network evolution contributes to China's control of the situation in the South China Sea and the development of scientific response strategies have realistic strategic value.

Exponential Random Graph Model is a kind of social network statistical model, which is one of the core methods to study the evolution of network relationship. International research on ERGM began in the 1980s,Frank and Strauss (1986) proposed the Markov Stochastic model, which laid the foundation for the ERGM model to be used in complex networks [1]; then the scholars had extended the Markov stochastic model so that the model can be assigned to the network data (Robins $G$, and Pattison P, 1999) [2];Skvoretz and Faust (2002) extended the model into a two-mode data network [3], and actor attributes were also incorporated into the ERGM model (Robins G and Elliott P, 2001) [4];Snijders founded that ERGM has a problem of model decay in terms of data estimation [5]. On this basis, he proposed an improved exponential stochastic model (Snijders TAB, 2006)[6],the simulation results of this model are more excellent. Then Simpson S L et al. (2012) improved and optimized the model with practical problems [7].Lusher D, Koskinen J and Robins G, (2013) introduced ,in detail, the various applications of the ERGM model in the book "Stochastic Dividend Graph Model of Social Networks: Theory, Methodology, and Application” [8].Wang P and Robins G (2016) used this model to study the farmer communication network of Ethiopian rural communities, and verified that the interconnection of network endogenous structure with other levels of network structure and the attributes of hierarchical nodes can affect the multi-layer network structure[9].

The World Economic Forum publishes the "Global Competitiveness Report" on a regular basis. The data in the report have been extensively evaluated and compared by the scholars, and the "Global Competitiveness Report” is a mature system for judging the determinants of a country's competitiveness, with the authority and reliability of the reliability and validity. Competitiveness is an important feature of a country's participation in the regional economic organizations and the global economic and trade activities. At the same time, the comprehensive nature of this indicator 
determines that it can reflect the economic and trade characteristics of a country.

\section{Research Object and Method Definition}

\section{Definition of Concept in “The south China sea issue” Stakeholders}

According to the preliminary results of the "The Analysis of Complex Network Evolution Process about "South China Sea Issue" Response" identified in 12 countries [10] after the expansion to 20 countries and regions, these countries and regions on the South China Sea dispute settlement have a substantial impact. The interests of the South China Sea issues defined as the table shown in Table 1 countries or regions by the purposes of different countries to participate in the "South China Sea issue":

Table 1. List of "South China Sea Issues” stakeholders

\begin{tabular}{|l|l|}
\hline Participation form & Country /region \\
\hline Domain dispute & $\begin{array}{l}\text { China (including Taiwan, China; Hong KongSAR; Macau } \\
\text { SAR), Philippines, Vietnam, Malaysia, Brunei, Indonesia }\end{array}$ \\
\hline Domain participation & Cambodia, Lao PDR, Myanmar, Singapore, Thailand \\
\hline Extraneous interference & Japan, United States, India, United Kingdom, Australia, Russia \\
\hline
\end{tabular}

\section{Research Methods}

The ERGM model is expressed as:

$$
\text { Eq. } 1 P_{r}=(X=x \mid Y=y)=\frac{1}{k} \exp \left(\theta^{T} z(x)+\theta_{a}^{T} z_{a}(x, y)\right)
$$

Where $\theta$ and $z$ are the parameters and statistics of the endogenous network effect, and $\theta_{a}$ and $z_{a}$ are the parameters and statistics of the social selection structure, involving the interaction between the network (x) and the attribute (y) variables. In the ERGM model of the trade network of the South China Sea stakeholders, the attribute (y) represents the actor attribute, and X represents the relationship in the trade network of service, which is the measure that the probability of generating a line in the network with the South China Sea stakeholders with a given actor attribute, the greater the probability of the condition, the greater the probability of generating the relationship between the nodes in the network under some kind of actor attributes, the greater the network density.

Using the data from the Eora MRIO database, according to the export of a node to the country's total exports of $2 \%$ of the binary processing, using $\mathrm{R}$ software to draw the South China Sea issue of stakeholders' service trade base network is shown in Figure 1:

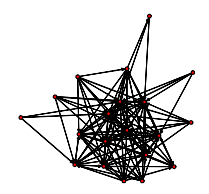

Figure 1 "South China Sea issue” stakeholders bilateral trade in services

\section{Analyze the Characteristics of South China Sea Issue Stakeholders' Service Trade Network Operators}

\section{Actor Attributes}

The service trade network of the interests of the South China Sea is a network system composed of economic and trade relations. Each country presents a different development trend in the trade network. According to the theory of social action, the characteristics and attributes of the actors affect the generation probability of the nodesdirectly in the network, thus affecting the evolution of the 
network structure. Global competitiveness index is a set of systematic and comprehensive index system, can be an objective assessment of a country's competitiveness, reflecting a country's trade base, policy characteristics, market-oriented and other characteristics. According to the Global Competitiveness Report 2013-2014, the actor-level attribute model shown in Table 2 can be constructed:

Table2 The first tier attribute of the Global Competitiveness Index

\begin{tabular}{|c|c|}
\hline Category & Index \\
\hline Basic requirements sub index & $\begin{array}{c}\text { Institutions, Infrastructure, Macroeconomic environment, } \\
\text { Health and primary education }\end{array}$ \\
\hline $\begin{array}{c}\text { Efficiency enhancerssubindex } \\
\begin{array}{c}\text { Innovation and sophistication } \\
\text { factors subindex }\end{array}\end{array}$ & $\begin{array}{c}\text { Higher education and training, Goods market efficiency, } \\
\text { Labor market efficiency, Financial market } \\
\text { development, Technological readiness, Market size }\end{array}$ \\
\hline
\end{tabular}

\section{ERGM Empirical Test of First - level Influencing Factors}

The model value of the actor attributes of Table 2 is assigned to the Y variable of the ERGM model, and the network data is generated by the network package in the $\mathrm{R}$ software. The statnet package simulates the South China Sea Issue Stakeholders' servicetrade network with node attributes, the results obtained in Table 3:

Table 3. Estimated results of continuous ERGM for service trade network taking into account the global competitiveness index

\begin{tabular}{|c|c|c|c|}
\hline Attribute name & ERGM estimates & Standard deviation & Significance \\
\hline Institutions & -0.7236 & 0.1017 & $<1 \mathrm{e}-04 * * *$ \\
\hline Infrastructure & -0.63748 & 0.08504 & $<1 \mathrm{e}-04 * * *$ \\
\hline Macroeconomic environment & -0.12488 & 0.07266 & 0.0865 \\
\hline Health and primary education & -1.1127 & 0.1621 & $<1 \mathrm{e}-04 * * *$ \\
\hline Higher education and training & -0.8606 & 0.1194 & $<1 \mathrm{e}-04 * * *$ \\
\hline Goods market efficiency & -0.9648 & 0.1443 & $<1 \mathrm{e}-04 * * *$ \\
\hline Labor market efficiency & -0.7993 & 0.1645 & $<1 \mathrm{e}-04 * * *$ \\
\hline Financial market development & -0.8657 & 0.1173 & $<1 \mathrm{e}-04 * * *$ \\
\hline Technological readiness & -0.54580 & 0.07716 & $<1 \mathrm{e}-04 * * *$ \\
\hline Market size & -0.55027 & 0.08491 & $<1 \mathrm{e}-04 * * *$ \\
\hline Business sophistication & -0.965 & 0.125 & $<1 \mathrm{e}-04 * * *$ \\
\hline Innovation & -0.7578 & 0.1111 & $<1 \mathrm{e}-04 * * *$ \\
\hline
\end{tabular}

Note: The attribute level in the table with the "NA" column indicates that the attribute's estimate is based on that level as a reference group.***, $* *$ and $*$ represent significant at $0.1 \%, 1 \%$ and $5 \%$ of the statistical level, respectively.

It can be seen that among the sub-indexes of global competitiveness, the other 11 indicators have significant influence on the generation of trade in services, except that the macroeconomic environment factor is not very relevant to the service trade network of "The south China sea issue" Stakeholders. The significant level reached the highest level of $0.1 \%$.From the estimation point of view, the impact of health and primary education, business sophistication and goods market efficiency on the survival and development of trade in services are the most significant, followed by the level of financial market development and higher education and training; Innovation, institutions and infrastructure have a moderate probability on the generation and development of trade in services. Market size and technical readiness' impact of the probability on the South China Sea issue stakeholders' services trade network relationship is relatively small. Therefore, to promote the development of services trade in the interests of the South China Sea, the countries and regions of various stakeholders need to focus on improving the level of health and primary education, take effective measures to promote business development, improve business maturity and commodity market efficiency; 


\section{Conclusion and Discussion}

1. There is a significant correlation between the Global Competitiveness Index and the generation (margin) of the service trade network of interest-related factors in the South China Sea, and the significant level is very high. It shows that the stronger the global competitiveness of the economy, the easier it is to promote the development of trade in services.

2. There is also a significant correlation between the infrastructure and the evolution of South China Sea stakeholders' the service trade network, and the improvement of the infrastructure of the economies in the network can promote the development of the overall service trade. The commercial development of commodity market directly related to the efficiency and maturity of the South China Sea issue stakeholders' services trade development.

3. The development level of financial market is an important factor on influencing the evolution of service trade network in the interests of the South China Sea. The development of financial markets in other economies is relatively low, which restricts the overall development of network services trade. Health and primary education is the two most critical factors on the service trade network, The development of the overall trade in services in Myanmar, Laos, Cambodia, Vietnam, Thailand, Russia and India are still at a low level in the quality of education in the South China Sea. This has a restrictive effect on the development of the overall service trade.

4. The level of higher education, the level of innovation, the efficiency of the labor market is also important factors that affecting the interests of the South China Sea economy's whole network of trade services. Most of the countries in the South China Sea problem lagged behind in these three areas, which in turn affects bilateral diplomatic relations.

\section{Attachment}

Attachment1. Data on the Bilateralization of Bilateral Trade in Borrowings for the South China Sea in 2013

\begin{tabular}{|c|c|c|c|c|c|c|}
\hline $\begin{array}{l}\text { Attributes } \\
\text { country / region }\end{array}$ & Institutions & Infrastructure & $\begin{array}{c}\text { Macroeconomic } \\
\text { environment }\end{array}$ & $\begin{array}{c}\text { Health and prima- } \\
\text { ry education }\end{array}$ & $\begin{array}{c}\text { Higher educa- } \\
\text { tion and train- } \\
\text { ing } \\
\end{array}$ & $\begin{array}{c}\text { Goods market } \\
\text { efficiency }\end{array}$ \\
\hline Australia & 2 & 2 & 2 & 1 & 2 & 3 \\
\hline Brunei Darussalam & 3 & 3 & 1 & 1 & 3 & 3 \\
\hline Cambodia & 4 & 4 & 3 & 2 & 4 & 3 \\
\hline China & 3 & 3 & 1 & 1 & 3 & 3 \\
\hline Hong Kong SAR & 2 & 1 & 1 & 1 & 2 & 2 \\
\hline India & 4 & 4 & 3 & 2 & 4 & 3 \\
\hline Indonesia & 4 & 3 & 2 & 2 & 3 & 3 \\
\hline Japan & 2 & 1 & 4 & 1 & 2 & 2 \\
\hline Lao PDR & 3 & 4 & 3 & 2 & 4 & 3 \\
\hline Macao SAR & 4 & 4 & 4 & 4 & 4 & 4 \\
\hline Malaysia & 3 & 2 & 2 & 1 & 3 & 2 \\
\hline Myanmar & 4 & 4 & 4 & 2 & 4 & 4 \\
\hline Philippines & 4 & 4 & 2 & 2 & 3 & 3 \\
\hline Russian Federation & 4 & 3 & 2 & 2 & 3 & 4 \\
\hline Singapore & 1 & 1 & 1 & 1 & 2 & 2 \\
\hline Taiwan,China & 3 & 2 & 2 & 1 & 2 & 2 \\
\hline Thailand & 4 & 3 & 2 & 2 & 3 & 3 \\
\hline United Kingdom & 2 & 1 & 4 & 1 & 2 & 2 \\
\hline United States & 3 & 2 & 4 & 1 & 2 & 3 \\
\hline Vietnam & 4 & 4 & 3 & 2 & 4 & 3 \\
\hline
\end{tabular}




\begin{tabular}{|c|c|c|c|c|c|c|}
\hline $\begin{array}{l}\text { Attributes } \\
\text { country / region }\end{array}$ & $\begin{array}{c}\text { Labor market } \\
\text { efficiency }\end{array}$ & \begin{tabular}{|c|} 
Financial mar- \\
ket \\
development
\end{tabular} & $\begin{array}{l}\text { Technological } \\
\text { readiness }\end{array}$ & Market size & $\begin{array}{l}\text { Business so- } \\
\text { phistication }\end{array}$ & Innovation \\
\hline Australia & 3 & 2 & 2 & 2 & 3 & 3 \\
\hline Brunei Darussalam & 2 & 3 & 4 & 4 & 3 & 4 \\
\hline Cambodia & 3 & 3 & 4 & 4 & 4 & 4 \\
\hline China & 3 & 3 & 4 & 1 & 3 & 4 \\
\hline Hong Kong SAR & 2 & 1 & 1 & 3 & 2 & 3 \\
\hline India & 3 & 3 & 4 & 1 & 3 & 4 \\
\hline Indonesia & 3 & 3 & 4 & 2 & 3 & 4 \\
\hline Japan & 3 & 3 & 2 & 1 & 2 & 2 \\
\hline Lao PDR & 3 & 4 & 4 & 4 & 4 & 4 \\
\hline Macao SAR & 4 & 4 & 4 & 4 & 4 & 4 \\
\hline Malaysia & 3 & 2 & 3 & 3 & 2 & 3 \\
\hline Myanmar & 3 & 4 & 4 & 4 & 4 & 4 \\
\hline Philippines & 3 & 3 & 4 & 3 & 3 & 4 \\
\hline Russian Federation & 3 & 4 & 4 & 2 & 4 & 4 \\
\hline Singapore & 2 & 2 & 1 & 3 & 2 & 2 \\
\hline Chinese Taipei & 3 & 3 & 2 & 2 & 2 & 2 \\
\hline Thailand & 3 & 3 & 4 & 2 & 3 & 4 \\
\hline United Kingdom & 2 & 2 & 1 & 2 & 2 & 3 \\
\hline United States & 2 & 2 & 2 & 1 & 2 & 2 \\
\hline Vietnam & 3 & 4 & 4 & 3 & 4 & 4 \\
\hline
\end{tabular}

Attachment 2. South China Sea Issues Stakeholder Services Trade Network Action Attributes Classification Table

\begin{tabular}{|c|c|c|c|}
\hline Icture & $\begin{array}{l}\text { The Global } \\
\text { Competi- } \\
\text { tiveness } \\
\text { Report } \\
\text { 2013-2014 }\end{array}$ & $\begin{array}{l}\text { Infrastructure construction includes a } \\
\text { national road, rail, port and air } \\
\text { transport, electricity supply, and tel- } \\
\text { ecommunications network construc- } \\
\text { tion. }\end{array}$ & $\begin{array}{l}\text { According to the country / region scores } \\
\text { are divided into four grades: } \\
\text { 1: } 6 \text { points or more (including 6) } \\
\text { 2: 5-6 points (including 5) } \\
\text { 3: } 4-5 \text { points (including 4) } \\
\text { 4: } 4 \text { points below }\end{array}$ \\
\hline In & $\begin{array}{l}\text { The Global } \\
\text { Competi- } \\
\text { tiveness } \\
\text { Report } \\
\text { 2013-2014 }\end{array}$ & $\begin{array}{l}\text { The institutional environment is de- } \\
\text { termined by the legal } \\
\text { and administrative framework within } \\
\text { which individuals, } \\
\text { firms, and governments interact to } \\
\text { generate wealth. }\end{array}$ & $\begin{array}{l}\text { According to the country / region scores } \\
\text { are divided into four grades: } \\
\text { 1: } 6 \text { points or more (including } 6 \text { ) } \\
\text { 2: 5-6 points (including 5) } \\
\text { 3: } 4-5 \text { points (including 4) } \\
\text { 4: } 4 \text { points below }\end{array}$ \\
\hline $\begin{array}{l}\text { Macroeco- } \\
\text { nomic envi- } \\
\text { ronment }\end{array}$ & $\begin{array}{l}\text { The Global } \\
\text { Competi- } \\
\text { tiveness } \\
\text { Report } \\
\text { 2013-2014 }\end{array}$ & $\begin{array}{l}\text { The index pays particular attention to } \\
\text { the assessment of the stability of the } \\
\text { macroeconomic environment. In- } \\
\text { cluding government budget balance, } \\
\text { total national savings, inflation, gov- } \\
\text { ernment debt and national credit rat- } \\
\text { ing. }\end{array}$ & $\begin{array}{l}\text { According to the country / region scores } \\
\text { are divided into four grades: } \\
\text { 1: } 6 \text { points or more (including } 6 \text { ) } \\
\text { 2: } 5-6 \text { points (including } 5 \text { ) } \\
\text { 3: } 4-5 \text { points (including 4) } \\
\text { 4: } 4 \text { points below }\end{array}$ \\
\hline $\begin{array}{l}\text { Health and } \\
\text { primary edu- } \\
\text { cation }\end{array}$ & $\begin{array}{l}\text { lobal } \\
\text { eti- } \\
\text { SS } \\
\text { t }\end{array}$ & $\begin{array}{l}\text { he level } \\
\text { alth ser- } \\
\text { uality of } \\
\text { cation. }\end{array}$ & $\begin{array}{l}\text { the country / region scores } \\
\text { to four grades: } \\
\text { more (including 6) } \\
\text { (including 5) } \\
\text { (including 4) } \\
\text { low }\end{array}$ \\
\hline $\begin{array}{l}\text { Highereduca- } \\
\text { tion and } \\
\text { training }\end{array}$ & $\begin{array}{l}\text { The Global } \\
\text { Competi- } \\
\text { tiveness } \\
\text { Report } \\
\text { 2013-2014 }\end{array}$ & $\begin{array}{l}\text { Some indicators measure the enroll- } \\
\text { ment rate of secondary and higher } \\
\text { education and the quality of educa- } \\
\text { tion, and the other measure the train- } \\
\text { ing of staff through vocational train- }\end{array}$ & $\begin{array}{l}\text { According to the country / region scores } \\
\text { are divided into four grades: } \\
\text { 1: } 6 \text { points or more (including 6) } \\
\text { 2: 5-6 points (including 5) } \\
\text { 3: 4-5 points (including 4) }\end{array}$ \\
\hline
\end{tabular}




\begin{tabular}{|c|c|c|c|}
\hline & & $\begin{array}{l}\text { ing to ensure that the skills of work- } \\
\text { ers can be improved. }\end{array}$ & 4: 4 points below \\
\hline $\begin{array}{l}\text { Goods market } \\
\text { efficiency }\end{array}$ & $\begin{array}{l}\text { The Global } \\
\text { Competi- } \\
\text { tiveness } \\
\text { Report } \\
\text { 2013-2014 }\end{array}$ & $\begin{array}{l}\text { The measure of whether the market } \\
\text { can provide customers with the right } \\
\text { products and services, whether to } \\
\text { ensure that these products and ser- } \\
\text { vices effectively in the market circu- } \\
\text { lation. Extreme tax system, discri- } \\
\text { minatory provisions against FDI will } \\
\text { affect the evaluation of this indicator. }\end{array}$ & $\begin{array}{l}\text { According to the country / region scores } \\
\text { are divided into four grades: } \\
\text { 1: } 6 \text { points or more (including } 6 \text { ) } \\
\text { 2: 5-6 points (including 5) } \\
\text { 3: } 4-5 \text { points (including 4) } \\
\text { 4: } 4 \text { points below }\end{array}$ \\
\hline $\begin{array}{l}\text { Labor market } \\
\text { efficiency }\end{array}$ & $\begin{array}{l}\text { The Global } \\
\text { Competi- } \\
\text { tiveness } \\
\text { Report } \\
\text { 2013-2014 }\end{array}$ & $\begin{array}{l}\text { The measure measures the efficiency } \\
\text { of a country's labor market and } \\
\text { whether the labor market is flexible. } \\
\text { Including the optimal allocation of } \\
\text { talent, the incentive mechanism for } \\
\text { labor at work and whether women } \\
\text { are treated fairly. }\end{array}$ & $\begin{array}{l}\text { According to the country / region scores } \\
\text { are divided into four grades: } \\
\text { 1: } 6 \text { points or more (including } 6 \text { ) } \\
\text { 2: 5-6 points (including 5) } \\
\text { 3: } 4-5 \text { points (including 4) } \\
\text { 4: } 4 \text { points below }\end{array}$ \\
\hline $\begin{array}{l}\text { Financial } \\
\text { market } \\
\text { development }\end{array}$ & $\begin{array}{l}\text { The Global } \\
\text { Competi- } \\
\text { tiveness } \\
\text { Report } \\
\text { 2013-2014 }\end{array}$ & $\begin{array}{l}\text { The indicators include the improve- } \\
\text { ment and soundness of the financial } \\
\text { sector in a country, the optimal allo- } \\
\text { cation of domestic and foreign finan- } \\
\text { cial resources, the number of financ- } \\
\text { ing channels in the financial markets } \\
\text { of the country, and the supervision of } \\
\text { financial markets. }\end{array}$ & $\begin{array}{l}\text { According to the country / region scores } \\
\text { are divided into four grades: } \\
\text { 1: } 6 \text { points or more (including 6) } \\
\text { 2: 5-6 points (including 5) } \\
\text { 3: } 4-5 \text { points (including 4) } \\
\text { 4: } 4 \text { points below }\end{array}$ \\
\hline $\begin{array}{l}\text { Technologi- } \\
\text { cal readiness }\end{array}$ & $\begin{array}{l}\text { The Global } \\
\text { Competi- } \\
\text { tiveness } \\
\text { Report } \\
\text { 2013-2014 }\end{array}$ & $\begin{array}{l}\text { Technical indicators measure the } \\
\text { agility of the economy using existing } \\
\text { technology to increase its industrial } \\
\text { productivity. This indicator considers } \\
\text { the ability to absorb and utilize new } \\
\text { technologies. Also the proportion of } \\
\text { Internet users, the proportion of } \\
\text { broadband Internet access, network } \\
\text { bandwidth and mobile Internet } \\
\text { access ratio to evaluate. }\end{array}$ & $\begin{array}{l}\text { According to the country / region scores } \\
\text { are divided into four grades: } \\
\text { 1: } 6 \text { points or more (including } 6 \text { ) } \\
\text { 2: 5-6 points (including 5) } \\
\text { 3: } 4-5 \text { points (including 4) } \\
\text { 4: } 4 \text { points below }\end{array}$ \\
\hline Market size & $\begin{array}{l}\text { The Global } \\
\text { Competi- } \\
\text { tiveness } \\
\text { Report } \\
\text { 2013-2014 }\end{array}$ & $\begin{array}{l}\text { Large-scale market can get econo- } \\
\text { mies of scale, the size of the market } \\
\text { and the degree of openness of trade. } \\
\text { The indicators include the domestic } \\
\text { market size and foreign market mod- } \\
\text { el, but also a country's GDP and ex- } \\
\text { ports accounted for the proportion of } \\
\text { GDP to measure. }\end{array}$ & $\begin{array}{l}\text { According to the country / region scores } \\
\text { are divided into four grades: } \\
\text { 1: } 6 \text { points or more (including 6) } \\
\text { 2: 5-6 points (including 5) } \\
\text { 3: 4-5 points (including 4) } \\
\text { 4: } 4 \text { points below }\end{array}$ \\
\hline $\begin{array}{l}\text { Business so- } \\
\text { phistication }\end{array}$ & $\begin{array}{l}\text { The Global } \\
\text { Competi- } \\
\text { tiveness } \\
\text { Report } \\
\text { 2013-2014 }\end{array}$ & $\begin{array}{l}\text { The overall indicators include the } \\
\text { quality of the national business net- } \\
\text { work and the level of private enter- } \\
\text { prise operations. The quality of the } \\
\text { national business network and sup- } \\
\text { port industry is measured by the } \\
\text { number and quality of local suppli- } \\
\text { ers, the degree of interaction between } \\
\text { suppliers. The level of private enter- } \\
\text { prise operations is evaluated through } \\
\text { corporate branding, marketing, dis- } \\
\text { tribution, production processes, } \\
\text { product production and enterprise } \\
\text { clustering. }\end{array}$ & $\begin{array}{l}\text { According to the country / region scores } \\
\text { are divided into four grades: } \\
\text { 1: } 6 \text { points or more (including } 6 \text { ) } \\
\text { 2: 5-6 points (including 5) } \\
\text { 3: } 4-5 \text { points (including 4) } \\
\text { 4: } 4 \text { points below }\end{array}$ \\
\hline Innovation & $\begin{array}{l}\text { The Global } \\
\text { Competi- } \\
\text { tiveness } \\
\text { Report } \\
\text { 2013-2014 }\end{array}$ & $\begin{array}{l}\text { Innovation requires a good social } \\
\text { environment and requires the com- } \\
\text { mon support of the public and private } \\
\text { sectors. Measuring the level of inno- } \\
\text { vation requires a number of indica- } \\
\text { tors, such as R \& D inputs, the num- } \\
\text { ber of high-quality scientific research }\end{array}$ & $\begin{array}{l}\text { According to the country / region scores } \\
\text { are divided into four grades: } \\
\text { 1: } 6 \text { points or more (including 6) } \\
\text { 2: 5-6 points (including 5) } \\
\text { 3: } 4-5 \text { points (including 4) } \\
\text { 4: } 4 \text { points below }\end{array}$ \\
\hline
\end{tabular}




\begin{tabular}{|l|l|l|}
\hline & $\begin{array}{l}\text { institutions and high-tech talent, the } \\
\text { degree of cooperation with industry } \\
\text { and education and intellectual prop- } \\
\text { erty protection. }\end{array}$ & \\
\hline
\end{tabular}

\section{Acknowledgement}

This research was financially supported by the Dalian Maritime University:3132016361.

\section{Reference}

[1]Frank O, Strauss D. Markov Graphs[J]. Journal of the American Statistical Association, 1986, 81(395):832 842.

[2]Robins G, Pattison P, Wasserman S. Logit models and logistic regressions for social networks: III. Valued relations[J]. British Journal of Mathematical and Statistical Psychology, 1999, 64(2):371 394.

[3]Skvoretz J, Faust K. Logit Models for Affiliation Networks[J]. Sociological Methodology, 2002, 29(1):253 280.

[4]Robins G, Elliott P, Pattison P. Network models for social selection processes[J]. Social Networks, 2001, 23(1):1 30.

[5]SnijdersTAB,Markov Chain Monte Carlo Estimation of Exponential Random Graph Models[J].Journal of Social Structure ,2002,3.

[6]Snijders T A B, Steglich C E G, Schweinberger M, et al. Manual for SIENA version 3.2 Provisional version[J]. Jonatasmuller Com, 2005, 14(2):257 258.

[7]Simpson S L, Moussa M N, Laurienti P J. An exponential random graph modeling approach to creating group-based representative whole-brain connectivity networks[J]. Neuroimage, 2012, 60(2):1117-26.

[8]Lusher D, Koskinen J, Robins G. Exponential Random Graph Models for Social Networks: Theory, Methods and Applications[M]. Cambridge University Press.2013

[9]Wang P, Robins G, Matous P. Multilevel Network Analysis Using ERGM and Its Extension[M]. Multilevel Network Analysis for the Social Sciences. Springer International Publishing, 2016. pp.125 143

[10]Zhao C P,Zheng M X,Fan H M. The Analysis of Complex Network Evolution Process about “South China Sea Issue” R esponse[J].China Soft Science,2016,(8):1 16.(in Chinese). 